Article

\title{
What Is the Role of the Government in Wildlife Policy? Evolutionary Governance Perspective
}

\author{
Krzysztof Niedziałkowski ${ }^{1,2, *}$ and Renata Putkowska-Smoter ${ }^{1,3}$ \\ ${ }^{1}$ Institute of Philosophy and Sociology, Polish Academy of Sciences, Poland; E-Mail: kniedzialkowski@ifispan.edu.pl (K.N.) \\ ${ }^{2}$ Mammal Research Institute, Polish Academy of Sciences, Poland \\ ${ }^{3}$ Faculty of Sociology and Education, Warsaw University of Life Sciences, Poland; \\ E-Mail: renata_putkowska-smoter@sggw.edu.pl (R.P.-S.) \\ * Corresponding author
}

Submitted: 30 January 2021 | Accepted: 13 April 2021 | Published: in press

\begin{abstract}
With the growing populations and range of large wild mammals in Europe, wildlife governance has grown in importance and provoked social conflicts, pressuring policy-makers to provide adequate policy responses. Some countries chose decentralised approaches, while others retain traditional top-down mechanisms. However, evolutionary mechanisms behind those changes and their impact on steering have attracted relatively little attention. We investigated the evolution of the governance of three wildlife species (European bison, moose, and wolf) in Poland (1945-2020) to map their existing paths and explore external and internal factors influencing steering patterns. The results suggest that despite the persistent dominance of state-centred governance and top-down hierarchical instruments characteristic for a post-socialist country, steering involved intense and often informal communication with influential actors. A growing diversity of actors and discourses in wildlife governance increased the state's steering options and improved conservation outcomes. Concurrently, the government's steering shifted from concrete policy results to managing tensions and interests within the field. These transformations helped to retain the effectiveness of steering in the changing context, while retaining state-dominated governance.
\end{abstract}

\section{Keywords}

carnivore conservation; environmental policy; institutional change; organisational theory; policy analysis; ungulate management

Issue

This article is part of the issue "Steering in Governance: Evolutionary Perspectives" edited by Kristof Van Assche (University of Alberta, Canada / University of Bonn, Germany) and Raoul Beunen (Open University, The Netherlands).

(C) 2021 by the authors; licensee Cogitatio (Lisbon, Portugal). This article is licensed under a Creative Commons Attribution 4.0 International License (CC BY).

\section{Introduction}

In recent decades, the populations of large mammals in Europe have increased in range and numbers, leading, in some areas, to a perception of overabundance (Carpio et al., 2020; Chapron et al., 2014). These processes were associated with a number of socio-economic factors, such as new pan-European regulations, structural changes in rural areas opening new habitats for wildlife, improved hunting management and a supportive public opinion (Boitani \& Linnell, 2015; Navarro \&
Pereira, 2015). Increasing wildlife populations exacerbated human-wildlife conflicts, and translated into calls for more participatory governance (Redpath et al., 2017). The responses of the European states differed depending on their policy-making styles, legislation, political history and traditions of wildlife management (de Boon et al., 2020; Putman, 2011; Stöhr \& Coimbra, 2013). The level of state intervention permitted in legislation and acceptable to the people can range from almost complete state control to practically no involvement (Putman, 2011). Although most countries adopt state-dominated 
governance, some took steps to decentralise decisionmaking (Bjärstig et al., 2014; Sandström et al., 2018). In federal countries, wildlife governance is dominated by regional authorities (de Boon et al., 2020; Stöhr \& Coimbra, 2013).

Literature on wildlife governance tends to focus either on existing governance arrangements or on the transformation from one mode of governance to another, while evolution within the modes is much less frequently explored. This involves the question of how the dominant state government responds to the changing context of policy-making while retaining its steering role and the effectiveness of interventions. This article aims at addressing this gap by exploring changes in the governance of three species (the European bison, the moose, and the wolf) in Poland. In contrast to Nordic and Western-European countries, the wildlife policies of post-socialist states have only been analysed to a limited extent, although these countries, depending predominantly on representative mechanisms and top-down, hierarchical steering (Börzel \& Buzogány, 2010; Niedziałkowski et al., 2016), have been successful in preserving some key charismatic wildlife during the turbulent 20th century. We used the Evolutionary Governance Theory (EGT; Beunen et al., 2015) as an organising perspective to explore the determinants of the stability of wildlife institutions and the role of the state in their dynamics, as well as to investigate challenges and opportunities connected with state steering in the context of socio-political transformations.

\section{Wildlife, Steering and the Evolutionary Perspective}

Literature advocating for more bottom-up governance of wildlife constitutes a strain of broader research that points to the growing complexity of environmental problems and highlights the inadequacies of centralised, hierarchical, expert-based models of decisionmaking (Armitage et al., 2012). Instead, it emphasises the need for decentralised, polycentric, cross-scale modes of inclusive governing involving state, market and society actors (Gunningham, 2009; Newig \& Fritsch, 2009). Particular attention is devoted to stakeholder participation that should facilitate the diversity of values and knowledge (Reed, 2009; Renn, 2006). The initial vision of governance as the 'hollowing out' of the state (Rhodes, 2007) was increasingly replaced with recognition that the state's role remains central as governments blend hierarchy with new collaborative approaches and engage in 'metagovernance': 'steering at a distance,' mobilising resources of various groups, and overseeing the process, while maintaining participants' autonomy (Kooiman, 2003; Meuleman, 2008).

'Steering' can be understood as "governing by setting the course, monitoring the direction and correcting deviations from the course set" (Crawford, 2006, p. 453). It requires: (1) being explicit about the direction and communicating it to those rowing; (2) establishing mech- anisms for verifying performance; (3) using knowledge and resources of other actors; and (4) installing regulatory mechanisms to stimulate and respond to the performance of rowing actors (Crawford, 2006). In governance literature, steering is seen broadly as the inclusion of various actors into governing through networks and soft law, in order to improve the process of policy formulation and implementation, but also in response to the growing bottom-up pressure of non-state actors (Capano et al., 2015; Meadowcroft, 2007). As the numbers of actors with various, often incommensurable goals increases, steering becomes more complex, especially concerning the need to coordinate policies across public sectors. The state's steering interventions can cover a spectrum from no steering at all, through various forms of participatory, decentralised and devolved networks, where governments 'steer at a distance,' to increasingly direct state interventions in representative systems, where policies ('steering') are implemented through the 'rowing' of public hierarchies and command-and-control instruments (laws, policies, administrative control) with little participation. Still, even in the latter, some forms of bottom-up influence and consultations with non-state actors may occur, and governments' steering may be bound by forces within and outside of particular policy sectors (Olsen, 2009).

In wildlife governance, the calls for more bottom-up approaches to mitigate human-wildlife conflicts resulted in many approaches stimulating stakeholder engagement: education and information, collaborative planning, community-based management, etc. (Nyhus, 2016). The record of such initiatives regarding environmental goals and social cohesion is mixed (Hansson-Forman et al., 2018; Kellert et al., 2000). Despite their focus on a wide range of stakeholders, participatory approaches require regulations, public policies and the involvement of the state for their effectiveness (Meadowcroft, 1998), and need to be crafted individually without blueprint solutions (Ostrom et al., 2007). Concurrently, the field for such designs is limited by the history or interactions between stakeholders, power structures, discourses and the dominant governance mechanisms (Sullivan, 2019; Voss et al., 2007). Another thing is, the state can be viewed not only as a powerful actor in wildlife governance but also as arenas of collective action, where key stakeholders vie for control of public policy (Avelino \& Wittmayer, 2016; Paavola, 2007).

The EGT (Beunen et al., 2015; Van Assche et al., 2013) conceptualises governance as the process of taking collectively binding decisions, that are continuously evolving in various locations and communities across scales through constant interactions between heterogeneous actors (public and private), representing different discourses, confirming or contesting formal and informal institutions (rules and tools of the game), and adapting to or altering the transforming materialities. At the same time, the evolution of governance is structured by dependencies: path dependencies (cognitive, organisational, 
material), current interdependencies between actors and institutions, and goal dependencies, associated with the impact of visions of the future on the reproduction of governance in the present. In the EGT, steering options are conditioned (both restricted and enabled) by co-evolutions in dialectical relationships between actors/institutions and knowledge/power. According to Beunen et al. (2015), steering always involves the participation of various actors, as successful steering requires the balancing of interests, although it is not always formally acknowledged. Understanding current steering options requires mapping of the governance path by exploring historical interactions between actors, institutions, power and knowledge, as well as the mapping of the wider socio-economic and environmental context of these interactions.

In the following, informed by EGT, we will trace the long-term development of Polish wildlife governance and the role of government steering based on the case studies concerning the governance of the European bison, the wolf and the moose. Our research questions are as follows: (1) How and in which context were the configurations of actors/institutions and knowledge/power evolving over the last century in Polish wildlife governance? (2) What was the impact of major historical shifts on the evolution of the policy domain? (3) How were the steering options of the state influenced by the evolution of governance and existing paths? (4) What were the steering goals of the state?

\section{Methods}

The research material came from two projects realised between 2015 and 2020, the results of which were published in three papers, where more detailed information and sources can be found (Niedziałkowski, 2019; Niedziałkowski \& Putkowska-Smoter, 2020; PutkowskaSmoter \& Niedziałkowski, 2020). The cases address three species representing different approaches to wildlife: (1) the European bison died out in the wild in 1919, and since then have been treated as a vulnerable species in need of protection; (2) the wolves were for the most part of the 20th century perceived as a harmful species (pest) requiring strong lethal control; (3) the moose were treated as a game species. We mapped the governance paths concerning these species and identified key events, groups of actors involved and recurring story-lines through the analysis of various texts published between 1920 and 2019 concerning their management. These included legal regulations and their official justifications, parliamentary proceedings, official policy documents and reports, publications in leading journals specializing in forest management, hunting, and nature conservation (e.g., Aura, Chrońmy Przyrodę Ojczysta, Łowiec Polski, Dzikie Życie, Las Polski, Przyroda Polska), and articles from popular press (e.g., Gazeta Wyborcza, Tygodnik Powszechny, Newsweek).

Additionally, in 2015-2019 we carried out 50 semistructured interviews with key stakeholders (Table 1), which helped us to identify informal rules in the analysed sub-domains and to clarify some parts of the discursive background not evident in the written material (e.g., the meanings of categories such as 'nature' and 'protection,' personal identities and interpretations of events). The interviewees were selected based on written sources and snowball-sampling. The interviews took between 25-130 minutes, and were assisted by an interview guide (see Supplementary File) with open-ended questions regarding: key events, key groups of actors involved, their discursive positions and impact on policy-making, and key challenges for wildlife governance. The interviews were transcribed and anonymised. We analysed the data collected through desk research and interviews with Atlas.ti software through theory-driven coding (Hsieh \& Shannon, 2005), in order to reconstruct the evolution of wildlife governance focusing on key events, actors, discourses, and institutions. This allowed us to identify and interpret patterns and differences in our case studies in a comparative manner.

\section{Results}

\subsection{The European Bison}

The European bison became extinct in the wild in the aftermath of World War I. Since 1923, various groups of actors collaborated both on a national and international level to reintroduce the species. In Poland, this collaboration involved state and non-state actors: zoologists, veterinarians, breeding specialists, foresters, hunters, and

Table 1. Number of interviewees by group of actors and by case.

\begin{tabular}{lccc}
\hline & The European Bison & The Moose & The Wolf \\
\hline Scientists & 8 & 7 & 7 \\
Foresters & 5 & $2 * *$ & $2 * * *$ \\
Hunters & - & 1 & 1 \\
Public Officials* & 9 & 2 & 2 \\
Activists & 2 & 2 & - \\
Journalists & - & 1 & 12 \\
TOTAL & 23 & 15 & 12 \\
\hline
\end{tabular}

Notes: ${ }^{*}$ including national park staff; ${ }^{* *}$ both foresters were also hunters; ${ }^{* * *}$ both hunters were also foresters. 
public officials. The state's involvement, perceived as crucial, was encouraged by framing bison restitution as a patriotic obligation. The bison were portrayed as requiring the constant support of experts in animal husbandry and breeding. Knowledge of actors involved and their learning-by-doing translated into successful and largely informal practices (e.g., feeding, transportation, veterinary work) and organisational arrangements contributing to bison restitution. Those institutions created a material and organisational legacy (e.g., breeding centres and organisations operating them) thus strengthening the path dependency. Formal rules were introduced only in 1938, when the bison became legally protected. Considering the steering options of the state, in this formative period, they were largely restricted to informal networking and the mobilisation of state resources to facilitate the bottom-up initiatives of the key groups, and restricted to the goals suggested by those groups. The members of these groups encouraged the state's steering, perceiving it as a guarantee for bison conservation in the long term.

After World War II, the role of the state's steering in bison governance strengthened, together with a general trend toward state dominance in public life, which is characteristic for the communist societies. The adopted goals were implemented by means of hierarchical, top-down governance and public organisations (national parks and state forest service). Still, some specific objectives (e.g., an optimal number of bison in the key site of the Białowieża Forest) were established informally by a wider range of actors, including various government departments with different preferences. As recalled by an interviewed bison manager:

There was a memo signed by Prof. Karpiński [director of the Białowieża National Park], Mr. Jaroński [government official], and Dr. Żabiński [expert in zoology] stating that the main goal of bison breeding in closed reserves would be releasing them into the wild, setting them free. And, obviously, it could not have been done so straightforwardly. It had to be intensively consulted with the State Forests Holding, because it was their territory. At some point one of the directors or ministers approved it, and after four years we could release two bulls [from the reserve] to see how they would behave.

In the mid-1970s, the government representatives and scientists from the ministerial advisory body decided to start controlling the population lethally. This was stimulated by pressure from the forestry administration as well as limited infrastructure. Stakeholders, operating largely within public organisations, negotiated the implementation details of this goal through informal conflicting, and the state became an arbiter of these internal struggles. Some steering institutions formalised in the form of administrative government consent for bison culling by forest and national park administrations. Despite the formal strict protection and the dominant discourse of bison as a vulnerable symbol of nature conservation, the species became lethally controlled and its population stopped growing.

After the democratic transition in 1989, the government became more environmentally conscious, mostly owing to new environmental NGOs and the expected EU accession. It developed an informal practice of allowing for less bison culling in the Białowieża Forest than requested by the managers. The population again started increasing and dispersing, but there was no clear goal of bison policy. Such new visions were presented shortly before Poland's EU accession by specialists in wildlife ecology, who criticised traditional arrangements, informed by zootechnical knowledge. They proposed expanding a few controlled populations and rewilding them to become more resilient to new risks associated with human interventions and climate change. They also lobbied the government and collaborated with other actors (foresters, local communities, NGOs) to install a new goal and create interdependencies (e.g., farmers receiving money for feeding bison). Bison management was supposed to be more adaptive, and based on scientific evidence provided by wildlife ecologists. The state welcomed these initiatives as an opportunity to improve bison governance and mobilise external resources for bison conservation. The new set of goals also increased the policy options that the government could pursue. Its consent, required for the application for EU resources, became an additional steering tool within the state's toolkit.

However, dominant actors defended the traditional paradigm and practices. One of the central figures, a professor of animal genetics and breeding, partially employed at the Ministry of Environment, established a bison conservation NGO and co-authored a bison conservation strategy, accepted by the ministry in 2007. It followed the traditional conservation discourse focused on the mitigation of conflicts with agriculture and forestry, and continuing proven practices but on a larger scale. The bison conservation NGO, with the government's consent, initiated new conservation projects with EU funding, which strengthened the community of bison managers and the resilience of existing approaches. The government, retaining control measures, allowed public and non-public actors to operate within the subdomain and negotiate both the goals and the means to implement them within the existing legal framework (both national and European), as well as to seek external resources for these purposes. The new EU context proved favourable to this mode of steering. The final shape of the actor/institutions and power/knowledge parameters of the sub-domain of bison policy depended on the effectiveness of different groups in mobilising resources and creating coalitions that the state acknowledged. Additionally, the state's support was also conditioned by the political situation - the liberal government supported the new discourse while the conservative one, 
in power since 2015, backed the traditional approach, strengthening the path.

\subsection{The Moose}

After World War I, the moose in Poland was close to extinction. The restoration of the species, legally considered to be game, was delegated by state authorities under hunting legislation to hunters and foresters who dominated the field of hunting. The former, associated within the Polish Hunting Association, were perceived as experts in wildlife management. The latter, employed by the public State Forests Holding, managed moose habitats. Their efforts increased moose population from a few individuals in the 1920 s to 1372 in 1938 . This success in the formative period of the moose policy in the newly established Polish state proved important for the further evolution of the sub-domain as it legitimised the key groups involved. After World War II, the restoration started from scratch, this time in the communist context. Again, foresters and hunters led the process as experts, and the steering of the state was restricted to the formal control of the activities of the dominant groups and goals that they prioritised. These groups, however, in the new socio-political context, became closely aligned with the state as part of the hierarchical public bureaucracies. The cooperation of foresters and hunters was facilitated by the shared discourse perceiving the moose as an object to be hunted in the future and the pre-war restitution as an inspiration and obligation. The moose was legally considered to be game, as the hunting regime was considered more effective in preventing illegal poaching than the conservation one. Restoration included guarding moose reserves and informing local communities about penalties for poaching. The moose population quickly increased to around 700 in 1967, and the hunting press started advocating selective shooting. In 1967, the dominant actors convinced the government that the moose was successfully restored and could now be hunted.

The moose numbers continued growing (to approx. 5100 in 1979) despite increasing hunting bag. Moose hunting, perceived as a unique experience, was profitable for local hunting clubs who could sell meat for exports. It also limited damages in forest plantations. Consequently, in the 1970s, the hunting pressure grew. In the early 1980 s, the quotas reached around 1500 moose annually and remained at 1200-1300 moose throughout the 1980s and early 1990s, although some wildlife and game biologists argued that it was unsustainable. In the late 1980s, scientists started criticising the lack of proper rules around moose hunting, pointed to alleged overestimating of official moose numbers, and proposed changes in the management of this issue. Socio-political changes in Poland after 1989 further increased harvesting, as hunters, uncertain of the prospective reform of game management, secured immediate gains. The state did not intervene in the hunt- ing policy as the dominant groups of actors in the field did not see the problem as requiring intervention.

At the same time, socio-political changes in Poland after 1989 made the government more open to the arguments of actors traditionally sidelined within the sub-domain (NGOs and conservation biologists) and to the use of new steering instruments from the field of nature conservation, rather than the hunting policy. The establishment of the Biebrza National Park (BNP) in 1993 could be seen as a key example of such a steering intervention in moose governance. The BNP included areas with the highest density of moose in Poland and significantly limited access to game. For the first time, a large moose population was protected, not for hunting but for conservation. Park managers implemented new rules without the involvement of foresters and hunters, which proved difficult to accept by those groups. However, the BNP was not enough to stop the population decline. In 2000, there were only approx. 1900 animals left, which challenged the effectiveness of hunting in sustaining moose populations. Responding to the crisis, hunters urged the government to introduce the proven tool of a moratorium on moose hunting, retaining its game status. It was to last 3-10 years until the moose population recovered. In 2001, the government introduced the moratorium but without specifying its duration, which could be interpreted as strengthening the state's steering beyond the traditional responses advocated by the dominant actors. After a few years, foresters started indicating growing damage in forests and increasing road accidents with moose. Perceiving the prolonged moratorium as a government failure to take responsibility for moose management, they also increasingly pressed authorities for some lethal control. In the meantime, environmental activists, whose influence grew after 1989, challenged the domination of the foresters and hunters - they called for open debates, wider public participation and the involvement of external experts and media. They portrayed the moose as a national treasure which should be accepted in Polish forests, despite the damages involved, and interpreted the 2001 moratorium as a failure of the traditional approach. The activists were supported by conservation biologists, who challenged the dominant actors' knowledge concerning moose management. This diversity of discourses and groups that represented them put the government in the position of an arbiter, which could pick policy options and steer the policy depending on the perceived state of the population and the socio-political context of the sub-domain.

Poland's accession to the EU in 2004 and the pressure for more participatory environmental policy-making strengthened the moratorium. In 2009, the government, looking for new policy options, commissioned an expert group, led by a wildlife biologist and including foresters and hunters, to prepare a strategy of moose management. The final document recommended limited hunting in four provinces, preceded by 3-5 years of partial 
protection under the nature conservation law. Also, it proposed a new government advisory group, including various stakeholders, to guide moose management. The strategy was not practically implemented, because it was vetoed by foresters and hunters, who associated the protected status with a passive approach towards nature, and did not trust that it would lead to the restoration of hunting. Still, the strategy became a reference point for the environmental actors, who considered the moratorium as a sub-optimal solution, but preferred it over the traditional hunting approach. The environmental actors were successful in publicising attempts to restore hunting by the government in 2014 and 2017, and mobilising public opinion against such initiatives. As recalled by an interviewed forester:

We started writing proposals [to the Ministry] to restore the moose hunting season and the Ministry always responded evasively. So we pointed out that a number of moose counts had been carried out and such-and-such a scientific expert authorised them. They responded that restoring the hunting season was out of the question but some moose could be shot for scientific purposes....And this scientific harvesting was cancelled after public outcry....Suddenly there was a phone call from the Ministry of the Environment: 'Stop moose shooting, because someone wrote something in the press.'

These attempts revealed the limits to the steering capacity of the state and the impact of foresters and hunters. It also showed that in order to set the direction and implement it practically, the state needed to engage to a larger extent in negotiation with different groups in the domain. So far, it has failed to do so and the moose policy can be characterised as drifting without clear policy goals.

\subsection{The Wolf}

In the formative period of wolf policy in Poland after 1918 , the species was considered to be game that that could be hunted throughout the year, and its governance was dominated by hunters. During World War II, the wolf population increased and hunters perceived this as a major problem affecting game resources and farm animals. They advocated a strong reduction of the species and pressed the government to organise an extermination action to limit losses for the national economy. In their view, the recognition of the problem by the state and its organisational and financial involvement was indispensable:

In order to plan and prepare this action [against the wolf] properly, it is necessary to recognise the importance of this issue at the governmental level, discuss, agree and issue a number of ordinances by the state authorities, ensure that these ordinances are properly understood by the executive branches and, finally, to prepare the Polish Hunting Association to complete tasks that it will be entrusted with. (Żebrowski, 1952, p. 8)

The government responded in 1955 using top-down, command-and-control steering instruments oriented at reaching the goals advocated by hunters. It proclaimed a comprehensive extirpation programme to be implemented by dedicated hierarchically organised public officials, and supported by high bounties. Its progress was assessed in hunting press, putting pressure on public authorities to strengthen their efforts. The programme proved successful, and by the mid-1970s, only around 60 wolves survived (less than $10 \%$ of the post-war population) in a few pockets in eastern Poland.

Since the 1960s, some game and wildlife biologists started suggesting that the wolf should not be exterminated because of its useful role in ecosystems. Their position was supported by international developments-in 1973, the International Union for Conservation of Nature (IUCN) published guidelines on wolf conservation urging for the restoration of wolf populations based on scientific evidence. In 1975, the government listed the wolf as a game species and curtailed the eradication efforts. The population started growing, and by 1990 it reached almost 900 individuals. The wolf was perceived as a competitor over the game and a prestigious prey, which needs to be kept at a 'reasonable' level through hunting. Wolf management was administered within hunting districts, either by the Polish Hunting Association or by the State Forests Holding, while supervised by the Ministry of Forestry. Specialists in game management provided scientific advice.

The socio-political transformation of Poland in 1989 stimulated the growth of environmental NGOs and, supported by the prospect of the EU integration, put environmental issues high on the political agenda. Because of personal connections with the new people in power and the greater accessibility of democratically elected politicians, environmental actors could intensively lobby for wolf protection. Wildlife biologists provided new data on wolf biology, challenging assumptions informing the dominant wolf governance-they highlighted the positive role of wolves in ecosystems and advocated their natural recovery. This provided the government with new steering options in terms of the goals of wolf governance and instruments that could be used-e.g., already in 1989 , the hunting of wolves in the Białowieża Forest, a key biodiversity hotspot, was stopped. As explained by an interviewed wildlife biologist:

After 1989 our academic tutor became a deputy minister of the environment in the new [democratically elected] government of Tadeusz Mazowiecki. We informed him that wolf numbers were overestimated and that, in fact, in such areas as the Białowieża Forest wolf hunting should be banned 
altogether....Being a biologist and an ecologist, he understood this very well and implemented [the hunting ban].

In 1991, a new Nature Conservation Act gave regional government representatives a legal avenue to protect wildlife. Wildlife biologists and NGOs started pressing them to list the wolf as a protected species. Consequently, several of the 49 provinces introduced wolf protection or strongly limited hunting. Activists were also lobbying the government to protect wolves across the country. Formally, the government could do this by means of executive regulation, but this would involve shifting wolf governance from the domain of hunting to the domain of nature conservation. Considering the position of hunters, the state was not ready to do this. In the view of environmental activists, government officials did not perceive the need to protect wolves, which the activists associated with their hunting background. To facilitate legal changes, some activists were even providing public officials with written justifications for new provisions. In 1995, faced with an increasing number of provinces transferring wolf governance to the nature conservation domain and recognising demands of the environmental actors, the government issued a regulation designating the wolf as a protected species in all but three provinces with high wolf densities. Two of these provinces soon introduced regional protection, and wolves could be hunted regularly only in the Krosno province. Despite the pressure of the activists, the Krosno governor retained hunting because of the opposition from hunters, foresters, herders, and some game specialists. Concurrently, the Polish Hunting Association tried to convince the government to restore wolf hunting in several provinces. While the government had various steering options at its disposal (either in the direction of protection or hunting), it did not implement them, due to opposing demands from the groups involved in the governance of the species.

The general election in 1997 proved critical for resolving the impasse. NGO activists convinced the new minister of the environment to protect wolves across the country. The official justification highlighted the wolf's role in balancing ecosystems and regulating ungulates. The government also introduced a compensation scheme for the farmers affected by wolf depredation. The new laws influenced the roster of groups involved in wolf management, transferring responsibilities from the hunting authorities to regional conservation offices and to the conservation department in the government. Some of the most vocal wildlife biologists prepared a wolf management strategy, commissioned by the ministry in 1998. In the following years, wolf populations grew rapidly, reaching around 2000 individuals in 2020 and inhabiting practically all major forest areas in Poland. Despite government changes and occasional pressure from hunters, foresters, herders, and supported by some game and wildlife biologists, the policy path initiated in 1998 has been followed. Its stability was facilitated by Poland's accession to the EU in 2004 and the conservation legislation it involved. After an administrative reform in 2007, which was supposed to improve the implementation of the Habitat and Birds Directives, the management of the wolf was transferred to a new state organisation-the General Directorate of Environmental Protection and its 16 regional branches. Compared with its predecessors, the new organisation had more responsibilities, more resources, and was more centralised. It also closely collaborated with various actors to fulfil its legal remit. Consequently, the steering capacity of the state in wolf governance strengthened, while its goals became limited to nature conservation priorities.

\section{Discussion and Conclusions}

In the preceding sections, we analysed the evolution of governance paths regarding three species of large mammals, focusing on the role of the actor/institutions and knowledge/power constellation and their impact on the various forms of steering involved. Despite apparent differences (management status, key actors involved) these paths shared many similarities, shedding some light on the evolution of the role of government steering. In each case, the government was legally and administratively the key actor formally responsible for the management of wildlife species defined as res communis (Putman, 2011) and, unlike in some other countries with state-dominated wildlife governance (Jacobson, 2008; von Essen et al., 2017), this position has been widely accepted by the key groups involved. It executed its mandate through hierarchically subordinate public organisations (the State Forest Holding, national parks) or by delegating some authority to the quasi-public Polish Hunting Association. Despite these typical command-and-control, top-down arrangements, the steering possibilities of the government in terms of setting policy goals, monitoring the direction, and correcting deviations from the course, did not have a top-down character and, despite legal opportunities, were not unlimited. Instead, as suggested by the EGT (Beunen et al., 2015), they were a matter of informal negotiations and conflicting between various public and non-public groups in particular policy sub-domains. Their results depended strongly on the ability of competing groups to mobilise different forms of resources (political, financial, interpersonal, organisational, cognitive). Knowledge turned out to be a key component in the struggles as it legitimised actors, their expert position, and gave them arguments to influence wildlife institutions.

As noted by Pierre and Peters (2019), much of the governance literature has ignored the question of who defined the goals of governance. Our study suggests that such goals should be considered at the level of concrete policy objectives and at the level of 'metagovernance.' In all cases, in formative periods, the sub-domains included one guiding discourse 
including particular constructions of animals and policy goals. These discourses, however, did not come from the government, but from the actors dominant in policy sub-domains. Such actors were able to convince the state that particular policy options were preferable and that they should be involved in their implementation. Consequently, together with government actors, they formed close policy communities (Rhodes, 1997), involved both in steering and rowing. In a relative conflictfree environment, these communities proved effective in reaching established policy goals (bison and moose restitution, wolf reduction). With the evolution of the governance paths, as foreseen by the EGT, the discursive landscape within the sub-fields diversified. This was stimulated by new international discourses (the wolf case), new fields of expertise connected with new conservation stages (the bison case), or by credibility crises of existing approaches (the moose case). Discursive changes were accompanied by the growing diversity of actors in policy sub-domains resulting from the divisions within the existing groups (e.g., scientists) and from new groups joining the discussions (e.g., environmental NGOs after 1989). Consequently, the networks involved in governance increasingly started resembling issue networks (Rhodes, 1997) with diverse groups of stakeholders representing different interests, views and values that problematised 'the future of nature' (Keulartz, 2009, p. 446).

Major socio-economic and political critical junctures (Collier \& Collier, 1991), especially the wars and the fall of the communist rule in 1989, as well as the EU accession in 2004, turned out to be particularly important for the pace of the evolution. First, these events influenced the state of the targeted populations, which subsequently led to increased efforts at species restitution or reduction. Secondly, they influenced the socio-political context of evolving governance structures that had an effect on the relationships between the actors in the field and on the shape of wildlife policies. The introduction of communism after 1945 strengthened the role of public hierarchies in the governance of wildlife due to the centralisation of administration and nationalisation of forests. The democratisation after 1989 and European integration opened windows of opportunities for new groups of actors in the sub-domains, influenced the responsiveness of the government, increased the access to resources and provided new venues where the conflicts could potentially be resolved (e.g., the European Court of Justice in the case of the species protected by the Habitat Directive). Consequently, the role of non-state groups in governance became more pronounced. Still, some paths initiated in the communist past have persisted, and include largely uncontested acceptance for the dominant role of the government in wildlife governance, as well as material legacies that encourage state steering, e.g., due to nationalisation, around $80 \%$ of forests in Poland (constituting key wildlife habitats) are state-owned.

The increasing complexity of wildlife governance after 1989 contributed to a transition of state steer- ing towards meta-governance (Meuleman, 2008)balancing interests and managing relations between diverse actors in the sub-domains to use their resources and achieve results that would present the government as competently dealing with policy problems, complying with its international obligations and satisfying the general public. This could be seen as a reflection of greater aligning control and accountability of the state for particular policies and orienting public policy by the larger collective interests, rather than by the interests of self-referential actors in the network (Pierre \& Peters, 2019). New actors problematised the role of science in wildlife management-it was still important, as it gave different groups credibility, but was rather supportive than essential for policy making (Rocheleau, 2017). In our cases this was because: (1) various groups had different epistemic communities they could reach to for evidence and it was difficult to establish one uncontested scientific assessment; and (2) the government tried to reach politically sustainable policy options rather than those best supported by scientific evidence. One of the manifestations of this co-evolution was the fact that the government ceased to produce clear wildlife policy goals, e.g., in the form of official strategies. Such strategies seemed to limit the state more than facilitating policy implementation. Consequently, one of the key aspects of the state's steering-being explicit about the objectives, norms and values and communicating it to those rowing (Crawford, 2006)-was compromised.

At the same time, growing diversity of actors and discourses, within the same formal framework, increased the capacities of the state to perform other requirements for steering-using resources of other (rowing) actors and verifying and responding to their performance (Crawford, 2006). The government did not depend on one dominant group of actors to define the problem and implement it, but could increasingly consider a wider spectrum of goals and implementation tools suggested by the competing coalitions and coming from the fields of game management and nature conservation. Furthermore, its monitoring capacities grew, as it could use the resources of other groups to verify information provided by dominant actors (e.g., wolf counts by hunters, bison damages in forest plantations assessed by foresters) and make more informed policy choices. This resembled the challenges to the 'monopoly of information' of 'subgovernments' in US wildlife politics after the rise of the environmental movement in the 1960s and 1970s, which helped government agencies to position themselves as 'intermediaries' between competing groups and gave them some leeway in choosing policy options (Nelson, 2001). Finally, due to co-evolutions in the sub-domains, the state could correct deviations from policies more effectively, going further than preferred by the dominant groups (e.g., prolonging the moose hunting ban).

However, increasing steering options did not mean that the state could use them at will. Its approach 
was influenced by wider structural factors: the socioeconomic context (e.g., socio-economic transition after 1989), legal context (e.g., EU directives), and the political situation (liberal vs. conservative governments; bottom-up societal pressure, e.g., against bison and moose hunting). Our cases also showed that the government was not always uniform in its approach, particularly with conservation, hunting and forestry departments representing different rationalities and policy communities. As noted by Peters (2011), governments often simultaneously steer toward several, sometimes incommensurable goals, which makes the process more complex, especially when policy goals change from relatively straightforward and undisputed (restitution of endangered species) to debatable (e.g., favourable conservation status). These external and internal factors limited the government steering capacity and opened windows of opportunity for new actors to influence policies.

The state was hardly a leader of policy innovation, yet its position as an ultimate-decision maker was not undermined due to powerful path dependencies and interdependencies - a vertical distribution of power, traditional top-down governance patterns, superior administrative capacities, legal powers, and ownership of key resources. Consequently, our cases problematise the assertion of Pierre and Peters (2019) that states are still capable of steering society, but less based on legal powers and more on the control of critical resources and shaping of collective interests (e.g., through new environmental policy instruments). We suggest that in post-socialist wildlife policies, both formal and material aspects of state governance have been crucial for government steering. Concurrently, steering and rowing turned out to be an 'interactive occupation' (Kooiman, 2003, p. 117), where goal seeking outweighed goal setting. Using the distinction of Voss et al. (2007), the state's steering increasingly moved from a problem of goals and knowledge to steering as a power problem, involving negotiation in networks, and as a problem of moderating co-evolution and reflexive governance to facilitate adaptation. Within existing legislation and political and cultural history, this mode of governance proved effective and contributed to the overcoming of gridlocks on wildlife issues often encountered in other countries (Rocheleau, 2017). Largely informal adaptations of the state's steering facilitated retaining the central role of government in wildlife governance despite significant socio-economic and political transformations that Poland experienced in the analysed period.

At the same time, the lack of clear policy goals from the state and associated policy instruments sustains tensions in the sub-domains, which contribute to increasing conflicts. This is particularly visible in the moose case, where the State Forest Holding notes growing damages in forest plantations, and in the wolf case, where growing wolf numbers concern local communities, especially in the newly established wolf territories. It is apparent that these conflicts will soon require adequate steering efforts from the state. Crucially, the state will need to identify the actors responsible for the management of these species locally. It can either restore previous hunting institutions informed by the utilitarian discourse and a sense of human control over the natural processes, or create new institutions and strengthen existing organisations (e.g., environmental agency) that would implement a more ecosystem-oriented and adaptive perspective on the ground. The international discourses and policy initiatives concerning biodiversity conservation (UNEP, 2021), EU priorities and legal framework, as well as considerable societal opposition to the lethal control of charismatic wildlife seem to create favourable conditions for the latter option. However, as suggested by the EGT, existing dependencies and power relations within the field might compromise more ambitious attempts at policy innovation. The political situation in Poland and the orientation of the Polish government at conservative or progressive values are also likely to play an important role in the future dynamics of wildlife governance.

\section{Acknowledgments}

The authors would like to thank the Polish National Science Centre for funding our research grants (No. 2015/16/S/HS6/00125 and 2017/27/B/HS6/03067) as well as the interviewees for contributing their time and sharing their thoughts on the investigated issues. We also thank the anonymous reviewers for their helpful suggestions.

\section{Conflict of Interests}

The authors declare no conflict of interests.

\section{Supplementary Material}

Supplementary material for this article is available online in the format provided by the authors (unedited).

\section{References}

Armitage, D., de Loë, R., \& Plummer, R. (2012). Environmental governance and its implications for conservation practice. Conservation Letters, 5(4), 245-255.

Avelino, F., \& Wittmayer, J. M. (2016). Shifting power relations in sustainability transitions: A multi-actor perspective. Journal of Environmental Policy \& Planning, 18(5), 628-649.

Beunen, R., Van Assche, K., \& Duineveld, M. (Eds.). (2015). Evolutionary governance theory: Theory and applications. Springer.

Bjärstig, T., Sandström, C., Lindqvist, S., \& Kvastegård, E. (2014). Partnerships implementing ecosystem-based moose management in Sweden. International Journal of Biodiversity Science, Ecosystem Services \& Management, 10(3), 228-239.

Boitani, L., \& Linnell, J. D. (2015). Bringing large mammals 
back: Large carnivores in Europe. In H. M. Pereira \& L. M. Navarro (Eds.), Rewilding European landscapes (pp. 67-84). Springer.

Börzel, T. A., \& Buzogány, A. (2010). Governing EU accession in transition countries: The role of non-state actors. Acta Politica, 45(1/2), 158-182.

Capano, G., Howlett, M., \& Ramesh, M. (Eds.). (2015). Varieties of governance: Dynamics, strategies, capacities. Palgrave Macmillan.

Carpio, A. J., Apollonio, M., \& Acevedo, P. (2020). Wild ungulate overabundance in Europe: Contexts, causes, monitoring and management recommendations. Mammal Review, 51(1), 95-108.

Chapron, G., Kaczensky, P., Linnell, J. D. C., Von Arx, M., Huber, D., Andrén, H., López-Bao, J. V., Adamec, M., Álvares, F., Anders, O., Balčiauskas, L., Balys, V., Bedő, P., Bego, F., Blanco, J. C., Breitenmoser, U., Brøseth, H., Bufka, L., Bunikyte, R., . . . Boitani, L. (2014). Recovery of large carnivores in Europe's modern human-dominated landscapes. Science, 346(6216), 1517-1519.

Collier, R. B., \& Collier, D. (1991). Shaping the political arena: Critical junctures, the labor movement, and regime dynamics in Latin America. Princeton University Press.

Crawford, A. (2006). Networked governance and the post-regulatory state? Steering, rowing and anchoring the provision of policing and security. Theoretical Criminology, 10(4), 449-479.

de Boon, A., Sandström, C., Arbieu, U., Hansen, I., Lehnen, L., Marino, A., Pohja-Mykrä, M., Risvoll, C., Strand, G.-H., \& Rønningen, K. (2020). Governing dual objectives within single policy mixes: An empirical analysis of large carnivore policies in six European countries. Journal of Environmental Policy \& Planning. Advance online publication. https://doi.org/ 10.1080/1523908X.2020.1841614

Gunningham, N. (2009). The new collaborative environmental governance: The localization of regulation. Journal of Law and Society, 36(1), 145-166.

Hansson-Forman, K., Reimerson, E., Sjölander-Lindqvist, A., \& Sandström, C. (2018). Governing large carnivores-Comparative insights from three different countries. Society \& Natural Resources, 31(7), 837-852.

Hsieh, H.-F., \& Shannon, S. E. (2005). Three approaches to qualitative content analysis. Qualitative Health Research, 15(9), 1277-1288.

Jacobson, C. (2008). Governance of state wildlife management: Reform and revive or resist and retrench? Society \& Natural Resources, 21(5), 441-448.

Kellert, S. R., Mehta, J. N., Ebbin, S. A., \& Lichtenfeld, L. L. (2000). Community natural resource management: Promise, rhetoric, and reality. Society \& Natural Resources, 13(8), 705-715.

Keulartz, J. (2009). European nature conservation and restoration policy-Problems and perspectives. Restoration Ecology, 17(4), 446-450.
Kooiman, J. (2003). Governing as governance. Sage.

Meadowcroft, J. (1998). Co-operative management regimes: A way forward? In P. Glasbergen (Ed.), Co-operative environmental governance: Publicprivate agreements as a policy strategy (pp. 21-42). Kluwer Academic Publishers.

Meadowcroft, J. (2007). Who is in charge here? Governance for sustainable development in a complex world. Journal of Environmental Policy \& Planning, 9(3/4), 299-314.

Meuleman, L. (2008). Public management and the metagovernance of hierarchies, networks and markets: The feasibility of designing and managing governance style combinations. Physica-Verlag

Navarro, L. M., \& Pereira, H. M. (2015). Rewilding abandoned landscapes in Europe. In H. M. Pereira \& L. M. Navarro (Eds.), Rewilding European landscapes (pp. 3-23). Springer.

Nelson, L. (2001). Wildlife policy. In C. Davis (Ed.), Public lands and environmental politics (pp. 223-250). Westview.

Newig, J., \& Fritsch, O. (2009). Environmental governance: Participatory, multi-level-and effective? Environmental Policy and Governance, 19(3), 197-214.

Niedziałkowski, K. (2019). Caught between the pasts and the futures? The role of imagined futures in the institutional dynamics of European bison conservation in Poland. Environmental Sociology, 5(4), 428-441.

Niedziałkowski, K., Pietrzyk-Kaszyńska, A., Pietruczuk, M., \& Grodzińska-Jurczak, M. (2016). Assessing participatory and multi-level characteristics of biodiversity and landscape protection legislation: The case of Poland. Journal of Environmental Planning and Management, 59(10), 1891-1911.

Niedziałkowski, K., \& Putkowska-Smoter, R. (2020). What makes a major change of wildlife management policy possible? Institutional analysis of Polish wolf governance. PLOS ONE, 15(4), Article e0231601.

Nyhus, P. J. (2016). Human-wildlife conflict and coexistence. Annual Review of Environment and Resources, 41(1), 143-171.

Olsen, J. P. (2009). Change and continuity: An institutional approach to institutions of democratic government. European Political Science Review, 1(1), 3-32.

Ostrom, E., Janssen, M. A., \& Anderies, J. M. (2007). Going beyond panaceas. Proceedings of the National Academy of Sciences, 104(39), 15176-15178.

Paavola, J. (2007). Institutions and environmental governance: A reconceptualization. Ecological Economics, 63(1), 93-103.

Peters, B. G. (2011). Steering, rowing, drifting, or sinking? Changing patterns of governance. Urban Research \& Practice, 4(1), 5-12.

Pierre, J., \& Peters, B. G. (2019). Governance, politics and the state. Macmillan Education.

Putkowska-Smoter, R., \& Niedziałkowski, K. (2020). Street level bureaucracy in response to environmen- 
tal pressure: Insights from forestry and urban green space governance in Poland. Environment and Planning C: Politics and Space. Advance online publication. https://doi.org/10.1177/2399654420972114

Putman, R. (2011). A review of the various legal and administrative systems governing management of large herbivores in Europe. In R. Putman, M. ApolIonio, \& R. Andersen (Eds.), Ungulate management in Europe: Problems and practices (pp. 54-79). Cambridge University Press.

Redpath, S. M., Linnell, J. D., Festa-Bianchet, M., Boitani, L., Bunnefeld, N., Dickman, A., Gutiérrez, R. J., Irvine, R. J., Johansson, M., Majić, A., McMahon, B. J., Pooley, S., Sandström, C., Sjölander-Lindqvist, A., Skogen, K., Swenson, J. E., Trouwborst, A., Young, J., \& MilnerGulland, E. J. (2017). Don't forget to look downCollaborative approaches to predator conservation. Biological Reviews, 92(4), 2157-2163.

Reed, M. G. (2009). A civic sort-of science: Addressing environmental managerialism in Canadian biosphere reserves. Environments, 36(3), 17-35.

Renn, O. (2006). Participatory processes for designing environmental policies. Land Use Policy, 23(1), 34-43.

Rhodes, R. A. W. (1997). Understanding governance: Policy networks, governance, reflexivity and accountability. Open University Press.

Rhodes, R. A. W. (2007). Understanding governance: Ten years on. Organization Studies, 28(8), 1243-1264.

Rocheleau, B. (2017). Wildlife politics. Cambridge University Press.
Sandström, C., Sjölander-Lindqvist, A., Pellikka, J., Hiedanpää, J., Krange, O., \& Skogen, K. (2018). Between politics and management: Governing large carnivores in Fennoscandia. In T. Hovardas (Ed.), Large carnivore conservation and management: Human dimensions (pp. 269-290). Routledge.

Stöhr, C., \& Coimbra, E. (2013). The governance of the wolf-human relationship in Europe. Review of European Studies, 5(4), 1-18.

Sullivan, L. (2019). Conservation in context: Toward a systems framing of decentralized governance and public participation in wildlife management. Review of Policy Research, 36(2), 242-261.

UNEP. (2021). Making peace with nature: A scientific blueprint to tackle the climate, biodiversity and pollution emergencies.

Van Assche, K., Beunen, R., \& Duineveld, M. (2013). Evolutionary governance theory: An introduction. Springer.

von Essen, E., Allen, M., \& Hansen, H. P. (2017). Hunters, crown, nobles, and conservation elites: Class antagonism over the ownership of common fauna. International Journal of Cultural Property, 24(2), 161-186.

Voss, J.-P., Newig, J., Kastens, B., Monstadt, J., \& Nölting, B. (2007). Steering for sustainable development: A typology of problems and strategies with respect to ambivalence, uncertainty and distributed power. Journal of Environmental Policy \& Planning, 9(3/4), 193-212.

Żebrowski, B. (1952). Sprawa wilcza [The wolf issue]. Łowiec Polski, 9(1006), 7-8.

\section{About the Authors}

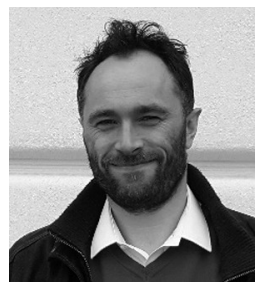

Krzysztof Niedziałkowski is an Assistant Professor at the Institute of Philosophy and Sociology, Polish Academy of Sciences. His academic interests include environmental sociology, environmental politics and environmental governance. His research concerns socio-political and environmental determinants of environmental policies. He is interested in the development of environmental institutions over time and their relationships with social controversies regarding the use of natural resources such as forests and wildlife.

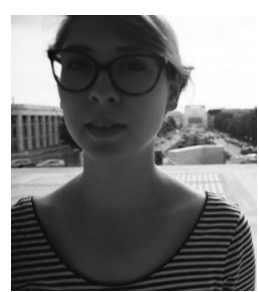

Renata Putkowska-Smoter is a Researcher at the Institute of Philosophy and Sociology, Polish Academy of Sciences and a lecturer at the Warsaw University of Life Sciences (WULS-SGGW). She is particularly interested in ambiguity and ambivalence towards nature and environmental protection and how they influence conflicts, governance, and politics on the local and national level. Currently, her research focuses on the perspective of the urban environmental street-level bureaucrats. 